\title{
Diplomatic Encounters. Jules Wabbes and the Production of American Dunbar Furniture in Brussels
}

In the first decades following the Second World War, several renowned American furniture brands entered the western European market. One of the well-known examples is Knoll International, a New York-based producer of "international style" furniture, which since 1951 set up sale and production licenses outside the US (Lutz 2010). Other American companies followed. This article discusses the introduction in 1959 of Dunbar furniture in Europe. The Indiana based Dunbar Company was known for producing an accessible version of modern design, which combined elements of traditional craft with a contemporary look (Gura et. al. 1997). The firm was introduced on the European market through a 1958 license agreement with the Brussels based Jules Wabbes, today considered one of the most original designers of high-end office furniture of his generation in Belgium (XXX 1958, Ferran-Wabbes et. al. 2012).

What motivated both parties to set up an official collaboration? As this article will show both Dunbar and Wabbes had the ambition to expand their clientele through contributing in the promotion of America's cultural and political identity in the Cold War years. One project in particular functioned as a catalyst in this process: the new American embassy in The Hague by architect Marcel Breuer. The interiors of this building were furnished with Dunbar furniture produced by Wabbes in Brussels. Although as a designer Wabbes remained in the background, the embassy project provided new opportunities in the identity construction of his own work, which he preferred to characterize as "universal".

keywords Dunbar, Jules Wabbes, Knoll, Belgium, Cold War

\section{Introduction}

\section{Jules Wabbes, furniture design and representation}

Designer and interior architect Jules Wabbes (1919-1974) is considered a maverick among the postwar furniture designers in Belgium. While in the 1950 a considerate part of Wabbes' colleagues had invested in the development of affordable or so-called social modern furniture, he was one of the few designers in Belgium to build up a convincing oeuvre of high standard furniture elements with strong representative qualities. One of his today well-known designs is the Gérard Philipe writing table (c. 1952) consisting of solid wooden slats glued together to form a rectangular tabletop with drawers and four elegantly styled steel legs (Fig. 1). A similar technique of glued slats was used to produce the rectangular or boomerang-shaped tabletops of Wabbes' executive desks from around 1957 with a characteristic steel framework pedestal, solid-wood drawers and metallic slides and handles. 
theme 3

identity

Figure 1.

Detail of the Gérard Philipe writing table by Jules Wabbes (c) Wim Van Nueten (photographer) and Ghent University, Department of Architecture and Urban Planning strand 1

design process and pratice

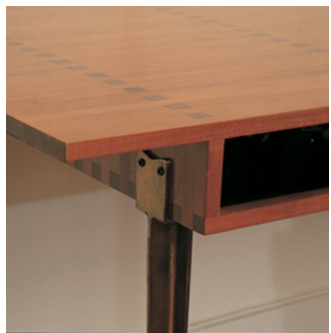

Also Wabbes' professional network was quite unique. Together with Louise Carrey, he explored the world of antique trading and interior design and from an early stage their clients included government officials and intellectuals. When in 1951 Wabbes started a collaboration with architect André Jacqmain, the office continued to attract important governmental and corporate clients, such as several state ministers and the Belgian airline Sabena. In short, the representative qualities of his work combined with a well-developed network of clients and design partners enabled Wabbes to firmly position himself on the Belgian market as an expert in the design of executive offices and other highly representative spaces.

\section{International aspirations}

As a designer and interior decorator Wabbes aspired international recognition. Since the mid 1950 s he often signed his designs with J.J. Wabbes adding an international flavor to his name and when in 1957 he established with Louise Carrey and Gustave Creyelman a company for the production and distribution of his furniture it was called Mobilier Universel. Wabbes particularly developed an interest in the United States. According to art historian Marie Wabbes, daughter of Jules Wabbes, this was triggered by his work for the Sabena airline company (Ferran-Wabbes 2002: 30). After all, the airline's request in 1955 to design the interior of six new airplanes produced by the American Douglas Aircraft Company for the first time allowed Wabbes to cross the ocean. Wabbes several times returned to the US. It was during one of those travels that he met with Edward Wormley (1907-1995), who according to Marie Wabbes, suggested the idea of Wabbes becoming the Dunbar furniture producer for Europe (Ferran-Wabbes 2010: 254).

By the time Wabbes met him, Edward Wormley had been working for Dunbar for over two decades (Gura et. al. 1997). Under Wormley's influence Dunbar had gradually modernized its collections to the point that since 1944 the company had decided to exclusively concentrate on modern furniture lines (Gura et. al. 1997). Nevertheless Dunbar's modern production of the postwar decades was quite different from that of contemporary American producers of modern furniture such as Knoll or Herman Miller. Contrary to the progressive nature of the products of the latter companies, Wormley's work is often characterized as combining a modernist approach with a strong sense of the past. Similar to Wabbes, Wormley strongly appreciated fine craftwork, liked to use luxurious materials including exotic woods and refined fabrics, and integrated historical allusions in his designs. For example his pentagonal coffee table from 1957 is made of walnut and is decorated with Tiffany glass tile inserts, which reference the American arts and crafts movement. 
Another parallel between the two designers was their ability to develop a well-elaborated network including close contacts within government circles. Crucial to the development of Wormley's professional network were his activities during World War II when he interrupted his work for Dunbar to head the Furniture Unit of the Office of Price Administration of the US Government. After the war Wormley resumed his work for Dunbar as an independent consultant. Also significant for the development of Wormley's professional network was his friendship since the 1930s with Edgar J. Kaufmann Jr. who later became Director of the Industrial Design Department at the Museum of Modern Art. Kaufmann included Wormley's work in the Good Design exhibitions and introduced him to several other emerging designers and architects.

Wormley often entertained guests in his New York apartment and Wabbes was one of them. In an undated letter to Louise Carrey, Wabbes gave a brief account of a dinner party organized by "the greatest American designer Edward Wormley" (Wabbes s.d.). Other guests included Vogue editor Alison Bisgood and editor of House Beautiful John Hill (Wabbes s.d.). Another well-known architect Wabbes established a good connection with was Philip Johnson. In a 1959 letter to William A.M. Burden, United States ambassador to Belgium, Johnson refers to the Belgian designer as "my friend Mr. Jules Wabbes who is a brilliant furniture designer and manufacturer in Brussels" (Johnson 1959).

Wabbes engaged in producing and distributing Dunbar designs in Europe, but he also hoped to come to an agreement on the production and distribution of his own designs in the US. In a letter to Wabbes dating from August 1958 Carrey expressed her confidence that in the near future this would be possible (Carrey 1998). Probably to support the possibility of an international break-through Wabbes from time to time also took the opportunity to praise his own work. "I have lots of work on hand at the moment," he explains in a 1959 letter to Gilbert Thurston, vice-president of Dunbar, "as my furniture, especially the desks, are meeting with bags of success, being preferred in many cases to those presented by Knoll" (Wabbes 1959). Wabbes' reference to Knoll is telling as this American firm since 1954 was represented in the Benelux - that is Belgium, the Netherlands and Luxembourg - through a license agreement with Kunstwerkstede De Coene (De Coene Art Workshop), a large scale Flemish family business (Floré 2012). In Belgium, as in other parts of Western Europe, Knoll furniture provided a welcome solution for the booming administrational sector, which was in need of representative, modern office furnishings. Furthermore Knoll easily found its way into the homes of a culturally progressive upper-middle class. Although their products obviously differed in style, to a considerable extent De Coene and Knoll and Wabbes, Mobilier Universel and Dunbar in Belgium targeted a similar clientele of corporate offices, governmental institutions and upper-middle class private commissioners.

\section{Producing American Furniture in the Cold War era}

In collaborating with American companies, De Coene and Mobilier Universel implicitly took a position in a new world conflict: that of the Cold War. After all, they both added to the growing visual representation of the American superpower in Western Europe. At first sight De Coene most directly supported the positive image of the US through its license contract with Knoll. In their 1981 monograph on the company, Eric Larrabee and Massimo Vignelli point out that, after the Second World War, Knoll was able to profit from the counterpart funds of the United States in Europe created by the Marshall Plan (Larrabee and Vignelli 1981: 176). For example, the US State Department placed a large order with Knoll for furnishings to be used in the diplomatic facilities expansion program. 
Also Mobilier Universel contributed to postwar representation of the US through collaborating with one of its major furniture brands, albeit in a more modest way. First of all Wabbes' furniture company was much smaller than De Coene. In 1961, when business was going well, Mobilier Universel employed 19 workers while De Coene was a large-scale furniture and building company in 1963 employing 1691 workers and employees. Moreover Dunbar developed a different expansion strategy than Knoll. While since the early fifties Knoll consequently invested in the establishment of production and branch-stores outside the US, Dunbar took a different approach. The company opened showrooms in many American cities, but Wabbes was one of the very few if not the only agent of the American firm in Europe (Johnson 2008). In addition the collaboration between Mobilier Universel and Dunbar did not involve the establishment of European flagship stores. In Brussels Dunbar was simply one of the foreign brands represented in the showroom of Mobilier Universel. In this showroom Wabbes combined his own work with Velca chairs (Italy), Kaufeld couches (Germany), Merivaara chairs (Finland), McGuire bamboo furniture elements (US) and Dunbar designs.

\section{Furnishing New American Embassies}

Mobilier Universel's contribution in the postwar representation of the American State was largely concentrated in one particular assignment: the furnishing of new embassy buildings. It is known that in 1954 the United States Department of State embarked on a new embassy-building program. In the following years many new American embassies were built in a modern architectural language. The interior design of these new buildings was the responsibility of Anita Moller Laird, chief of the interior design group of the FBO. As architectural historian Jane Loeffler explained, during the years when foreign credits were available Moller purchased "foreign-made copies of American furnishings under special agreements with various manufacturers" (Loeffler 1998: 93).

It seems more than likely that the new embassy-building program strongly motivated the contract between Dunbar and Wabbes. According to a letter of 1 August 1958 from Gilbert Thurston to Anita Moller, Moller, Thurston and Carrey had a professional meeting in Washington only about one month after the agreement between Dunbar and Wabbes was signed. The letter was intended to reassure Moller that Mobilier Universel would be able to manufacture "fine furniture along the American style and craftsmanship" (Thurston 1958). The meeting with Moller must have went well as Carrey states in a letter to Wabbes from 11 August 1958 that there is a 75\% chance that Mobilier Universel will be able to supply the Dunbar furniture for the new American embassy in The Hague (Carrey 1958).

By the end of 1958 the job came through and Wabbes was asked to manufacture and install the furnishings for the new US embassy in the Netherlands. Most of the furniture in the embassy was designed by Edward Wormley (Galema and Hooimeijer 2008) (Fig. 2). The choice of the State Department for Dunbar furniture was a diplomatic one. Several earlier postwar embassies had been furnished by Knoll and had met with a lot of criticism (Loeffler 1998: 57). The modern appearance of the Knoll furniture was often considered inappropriate and the quality of the construction was questioned. In addition the way architects received government commissions was criticized (Loeffler 1998: 67). The architect"s budget often included that for interior decoration, which allowed him or her to involve companies like Knoll without much discussion. With the new embassy-building program things were organized differently. First of all Moller directly negotiated with Dunbar and Mobilier Universel. Wabbes only met Breuer a few months before the building would finally open. Furthermore by choosing Dunbar Anita Moller opted for an accessible 
version of modern design, which contrary to Knoll explicitly valued historical references and refined craftsmanship. Finally clear efforts were made to guarantee that foreign production of the Dunbar furniture would be of good technical quality.

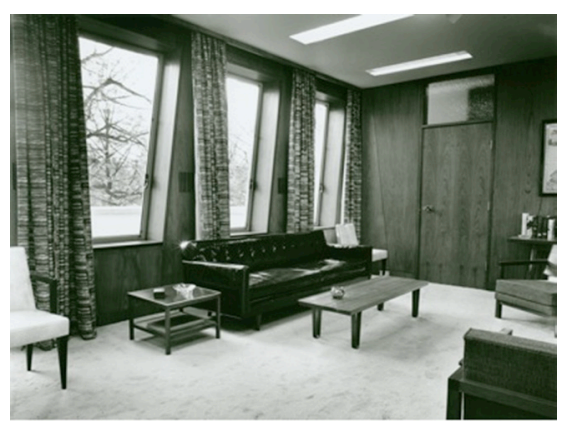

Figure 2.

Interior of the American Embassy in The Hague (C) Marie Ferra-Wabbes

As a designer Wabbes' contribution to the The Hague embassy was limited. Marie Wabbes mentions a plywood paper tray designed by her father for the embassy, but up till now there is no concrete evidence that other designs by him were integrated in the interiors. Nevertheless the State Department must have been impressed with Wabbes' work as not much later he was hired to design and execute the interior of the new American embassy in Rabat. This time he combined own designs with Dunbar furniture.

\section{Conclusion}

As this paper has shown the postwar promotion of the cultural and political identity of the US stimulated international exchange and engendered new business possibilities for ambitious local enterprises. In the Belgian case not only large-scale companies such as De Coene took advantage of this situation to explore new markets and negotiate a modern identity. Also Wabbes seized the opportunity to strengthen and promote the "universal" cultural identity his work was meant to express.

\section{Acknowledgments}

The author wishes to thank Marie Wabbes for her most generous collaboration and feedback.

\section{References}

XXX (1958) 'Manufacturer's and distributor's agreement', unpublished document, 27 June 1958, Paris: Jules Wabbes private archives.

Carrey, L. (1958) unpublished letter to Jules Wabbes, received on 11 August 1958, Paris: Jules Wabbes private archives.

Ferran-Wabbes, M. (2002) Jules Wabbes 1919-1974. Binnenhuisarchitect, Doornik/ Brussel: La Renaissance du Livre/Dexia.

Ferran-Wabbes, M. (2010) Jules Wabbes, Ghent: Borgerhoff \& Lamberigts.

Ferran-Wabbes, M., Persijn, J. and Strauven I. (eds.) (2012) Jules Wabbes. Furniture Designer, Brussels: A+Editions/Bozar Books.

Floré, F. (2012) 'Architect-designed interiors for a culturally progressive upper-middle class : the implicit political presence of Knoll International in Belgium', in Schuldenfrei, R. (ed.) Atomic dwelling. anxiety, domesticity, and postwar architecture, Abingdon/New York: Routledge: 169-185. 
Galema, W. and Hooimeijer, F. (2008) Bouwen aan diplomatie. De Amerikaanse ambassade in De Haag. Marcel Breuer 1956-1959, Den Haag: Gemeente Den Haag. Gura, J., Kennedy, C. and Weinberg L. (eds.) (1997) Edward Wormley. The Other Face of Modernism, New York: Designbase/Lin-Weinberg Gallery.

Johnson, E. (2008) 'Edward Wormley,' in Merrill, T. and lovine, J. V. (eds.) Modern

Americana. Studio Furniture from High Craft to High Glam, New York: Rizzoli: 216-227. Johnson, Ph. (1959) unpublished letter to William A.M. Burden, United States Ambassador to Belgium, 2 November 1959, Paris: Jules Wabbes private archives. Larrabee, E. and Vignelli, M. (1981) Knoll Design, New York: Abrams. Loeffler, J. (1998) The Architecture of Diplomacy. Building America's Embassies, New York: Princeton Architectural Press.

Lutz, B. (2010) Knoll. A Modernist Universe, New York: Rizzoli, New York. Thurston, G. L. (1958) unpublished letter to Anita Moller, 1 August 1958, Paris: Jules Wabbes private archives.

Wabbes, J., (s.d.) unpublished letter to Louise Carrey, Paris: Jules Wabbes private archives. Wabbes, J. (1959) unpublished letter to Gilbert Thurston, 12 January 1959, Paris: Jules Wabbes private archives. 